\title{
Den tidlige industrialisering i hertugdømmet Slesvig $1830-1864$
}

\author{
af Hans SCHultz HaNSEN
}

2007 er Industrikulturens År. Som optakt hertil bringer Sønderjyske Årbøger en artikel om den tidlige industrialisering $i$ hertugdømmet Slesvig mellem 1830 og 1864. Den er skrevet af arkivar, forskningsleder, dr.phil. Hans Schultz Hansen, Landsarkivet for Senderjylland. I denne periode af 1800-tallet var der en ikke ubetydelig industriel udvikling med afsæt først og fremmest $i$ teglværkerne, jernstøberierne og tobaksfabrikkerne. Ved midten af $1850^{\prime}$ erne blev højdepunktet nået med 250 industrivirksomheder med tilsammen 5.200 ansatte.

\section{Indledning}

Industrien i hertugdømmet Slesvig har rødder tilbage til 1600- og 1700-årene. Kobbermøllen ved Kruså blev udbygget til et kobberhammerværk i 1630'erne på grundlag af et ældre anlæg fra 1500-tallet. I Ascheffel i Hütten sogn anlagdes en papirfabrik i 1633, i Flensborg en i 1699. I anden halvdel af 1700-tallet blev der iværksat flere, tildels stort anlagte industriprojekter. I Slesvig by blev 1754-56 grundlagt en fajancefabrik, en kniplingstrådfabrik og en kammerdugsfabrik. I Egernførde oprettede den velhavende familie Otte i 1761 et uldmanufaktur og en fajancefabrik. Ved Haderslev blev »industrieventyret« i Christiansdal indledt i 1771 med grundlæggelsen af blikfabrikken "Godthåb «, ligesom brødremenighedskolonien Christiansfeld fra 1773 hurtigt skabte flere fabrikker: et linned- og bomuldsvæveri, et uldtøjsvæveri, et strømpevæveri, et garveri, et lysestøberi og sæbesyderi, en amidam- og pudderfabrik, en båndfabrik og en segllakfabrik. ${ }^{1}$

Adskillige af disse 1700-tals fabrikker fik kun kort levetid. Ofte var de mere baseret på privilegier fra statsmagten, der ønskede monarkiets nationaløkonomi styrket ved egenproduktion af industrivarer, end på en konkurrencedygtig produktion til et købedygtigt marked. Der- 
Kobbermollen ved Kruså hørte til hertugdømmet Slesvigs xldste industrier. Varket blev grundlagt af Christian IV i 1630'erne. I perioden 1811-1863 havde Kobbermollen mellem 30 og 60 medarbejdere. Den horte ikke længere til blandt de storste industrivirksomheder. Maleri fra tiden ca. 1855-1869 $i$ privateje, her gengizet efter Slesvigland 1998.

for kom de sjældent til at øve indflydelse på 1800-tallets mere udbredte industrialisering, men må snarere betragtes som en industri før denne, med andre ord som en protoindustri. Anderledes gik det inden for teglfremstillingen. Omkring Flensborg fjord udviklede en række »bondeteglværker « sig i løbet af 1700 -tallet til en permanent og omfattende industri, hvis betydning rækker frem til i dag.

Det er imidlertid først omkring 1830, at den industrialisering begyndte, som siden har formået at sætte sit afgørende præg på den dansk-tyske grænseregion. Her skal de forste tre-fire årtier af denne proces - den tidlige industrialisering - følges frem til 1864. Først fra 1870 'erne satte den bredere og dyberegående industrialisering ind, som grundlæggende forandrede samfundet. Dennes forløb i provinsen Slesvig-Holsten er nu grundigt beskrevet med særligt henblik på Nordslesvig af Leif Hansen Nielsen. ${ }^{2}$

Den tidlige industrialisering af Slesvig er ligeledes behandlet af den industrihistoriske forskning. ${ }^{3}$ Gerd Vaagt har beskrevet Die frïhe Industrialisierung im Herzogtum Schleswig i festskriftet Flensburg 700 Jahre Stadt (1984), mens Lars N. Henningsen har skildret Sonderjyllands tidligste industrialisering for 1864 - personer og konjunkturer (Industrihistorisk Selskab for Sønderjyllands skrift nr. 1 fra 1992). Disse to korte oversigter beskæftiger sig begge særlig med jernindustrien og dens iværksættere. For tiden indtil 1845 er industrien bredt skildret af Nicolai Haase i bogen Das Aufkommen des gewerblichen Grossbetriebes in Schleswig-Holstein (1925), men også her uden noget samlet statistisk udtryk for industrialiseringen. Det forsøges til gengæld for Nordsles- 
vigs vedkommende i Vibeke Harsberg bog Træk af den sønderjyske industris udvikling 1850-1864 (1988), men afhandlingens geografiske afgrænsning alene til området nord for 1920-grænsen skaber problemer. Begge bøger bygger på de bevarede fabrikslister. Det gør tillige Ulrike Albrechts Das Gewerbe Flensburgs von 1770 bis 1870 (1993), der dog medtager de helt små virksomheder med en håndværksmæssig produktion, uden at de industrielle foretagender kan udsondres. I bogen Frühindustrialisierung in Schleswig-Holstein, anderen norddeutschen Ländern und Dänemark, redigeret af Jürgen Brockstedt (1983), findes dels redaktørens grundige indledende oversigt, dels en række solide branche- og lokalstudier, hvoraf skal nævnes Lars N. Henningsens bidrag om jernstøberier og maskinfabrikker i Nordslesvig 1840-1920 (på dansk i Sønderjyske Årbøger 1982), Gerd Vaagts om jernindustriens start i Flensborg, Henrik Fangels om industriens begyndelse i Haderslev 1840-1870 samt Peter Wulfs om M.H. Holler og grundlæggelsen af den store jernvirksomhed Carlshütte i Büdelsdorf nord for Rendsborg. Wulf har skrevet om andre tidlige foretagere $\mathrm{i}$ artiklen Frühe schleswig-holsteinische Unternehmer i antologien Schleswig-Holsteins Weg in die Moderne (1988). Derudover findes adskillige arbejder om enkelte virksomheder, bl.a. Jens-Uwe Lemburgs bog Arbeit auf der Hütte (1990) om jernstøberiet og maskinfabrikken Carlshütte.

Den hidtidige forskning behandler således nok enkelte brancher, lokaliteter eller perioder, men giver intet samlet statistisk overblik over industrialiseringen i hertugdømmet Slesvig 1830-64 omfattende samtlige brancher og lokaliteter. Et sådant overblik tilsigtes med denne undersøgelse, der til gengæld vil begrænse sig til at belyse den tidlige industri alene ved antallet af virksomheder og beskæftigede arbejdere og kun i hovedtræk belyse udviklingen i de enkelte brancher. Artiklen er således mere et supplement til den eksisterende forskning end en sammenfatning af denne.

\section{Fabrikslisterne}

Kildegrundlaget for den følgende redegørelse er de såkaldte fabrikslister med indberetninger om industrivirksomhederne, deres ejere, medarbejderstab, råvareforbrug og produktion. Disse lister blev indsamlet årligt fra 1774 (i udbygget form fra 1809) og indtil 1863. ${ }^{4}$

Listerne er desværre ikke konsekvent bevaret. For adskillige år mangler de helt, og for andre år er bevaringen ukomplet, idet der 
savnes lister fra enkelte byer og amter. Det er dog muligt at opnå en tilnærmelsesvis fuldstændig dækning for en række af år, der ligger med en 6-8 års mellemrum. Det drejer sig om årene 1830, 1837, 1845, 1851, 1857 og 1863. Til sammenligning bringes endvidere tal fra 1811. Om nødvendigt er mangler $i$ listerne udfyldt med tal fra lister fra de nærmest omkringliggende år. Listernes opbevaringssteder, deres eventuelle mangler og mulighederne for at kompensere for disse fremgår af fortegnelsen i slutningen af denne artikel. Om listen for 1863 bemærkes, at oplysningerne forst blev indsamlet $\mathrm{i}$ begyndelsen af 1865. Lægges hertil turbulensen som følge af krigen i 1864 og Slesvigs afståelse til Preussen og Østrig, må det formodes, at adskillige virksomheder, som var i drift i 1863, er forsvundet og dermed udgået af datamaterialet. Derfor er tilbagegangen i antallet af virksomheder og ansatte muligvis større end i virkelighedens verden. At der var tilbagegang, er dog indiskutabelt. ${ }^{5}$

Selv på de mest velbevarede fabrikslister kan oplysningerne ikke uden videre antages som fuldgyldige. Dels kan antallet af medarbejdere være underdrevet af ejeren ved indberetningen for ikke at bibringe myndighederne indtrykket af en større indkomst og dermed et rigere skattegrundlag end strengt nødvendigt. Dels kan det konstateres, at enkelte virksomheder mangler af grunde, som er mere eller mindre gennemskuelige. Således optræder skibsværfterne kun sporadisk i listerne, skønt det kunne dreje sig om ret så betydelige virksomheder, særligt set fra en lokal synsvinkel. Formentlig er de udelukket, fordi der her trods størrelsen var tale om en håndværksmæssig produktion udført på bestilling. ${ }^{6}$ Der fandtes særlige lister over skibsbyggeriet; men de tog nok så meget udgangspunkt i de producerede skibe som i skibsværfterne, og de blev hverken så konsekvent udfyldt eller er så godt bevaret som fabrikslisterne. Derfor er det kun muligt til sidst at give spredte tal for skibsværfterne.

Listerne medtog $\mathrm{i}$ henhold til datidens almindelige opfattelse af fabrikker kun virksomheder, der producerede varer gennem forarbejdning af råstoffer. ${ }^{7}$ Imidlertid findes der ofte i den første tid på listerne virksomheder, der falder udenfor en mere moderne definition af industri. Ifølge denne forstås ved industri fremstillingsvirksomheder, der i produktionen anvender maskiner drevet ved mekanisk kraft. Disse maskiner bestemmer rytmen i produktionen og forudsætter en vidtgående arbejdsdeling mellem medarbejderne, der alle varetager deres særlige led i processen. Endelig masseproducerer indu- 

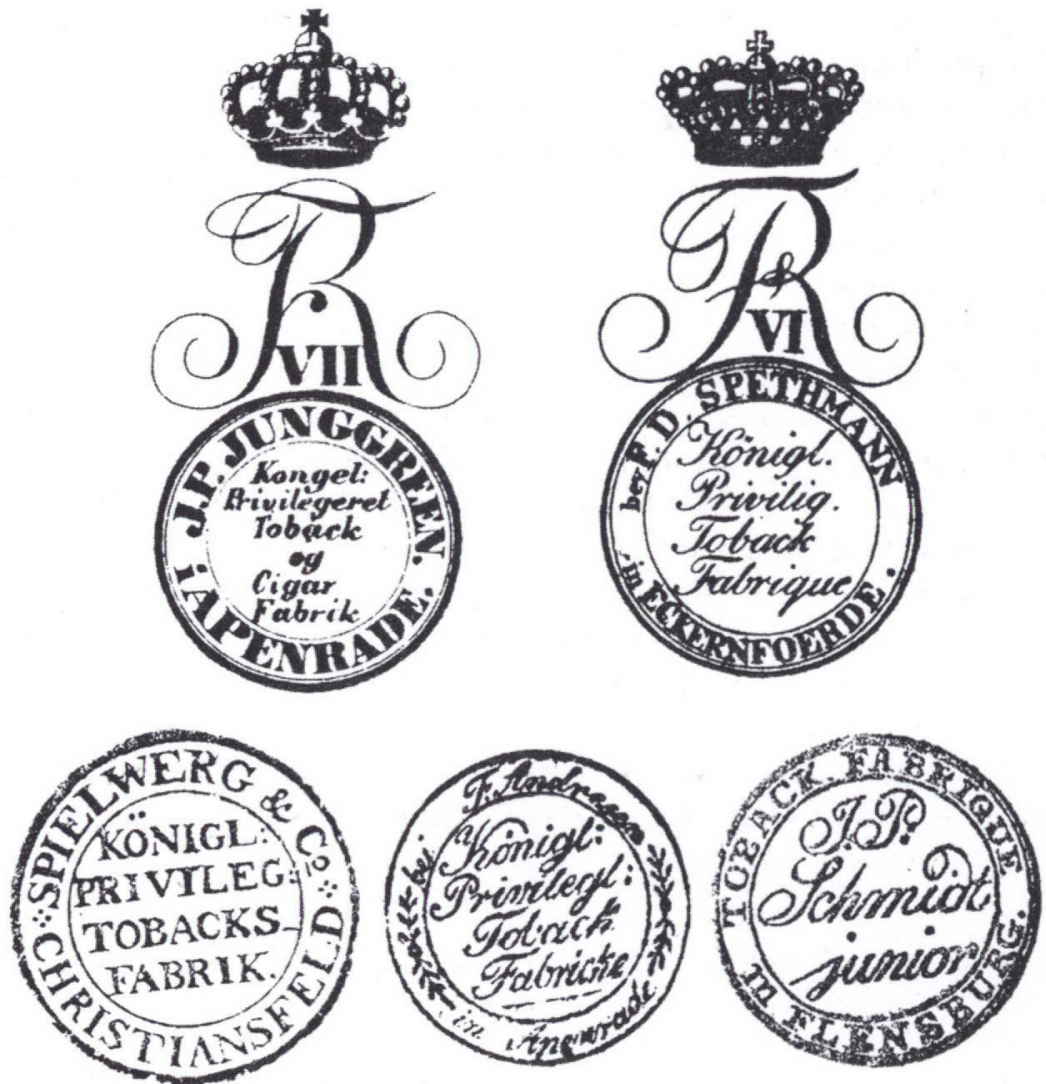

Den slesvigske tobaksindustri voksede $i$ takt med velstandsudviklingen op gennem 1800-tallet. Det var en industri, hvor den menneskelige arbejdskraft, ikke mindst kvinder og born, vedblev at spille en stor rolle i produktionen. Maskiner vandt kun til dels indpas. Billedet viser fabriksstempler fra kendte slesvigske tobaksfabrikker fra tiden ca. 1820-1856. De skulle stemples på varerne for at forhindre bedragerier med tolden. Efter Sønderjysk Månedsskrift 1978 s. 135.

strien efter den moderne forståelse varer til et anonymt marked. ${ }^{8}$ I modsætning til denne definition rummer fabrikslisterne mange helt små virksomheder, som ikke kan have haft nogen vidtgående arbejdsdeling, men en håndværksmæssig produktion. For at udelukke dem er undergrænsen for industri i det følgende sat ved seks arbejdere, svarende til den moderne industristatistik. Derudover har fabrikslisterne foretagender, som nok havde mange medarbejdere, men som på andre punkter ikke levede op til den ovenstående moderne defini- 
tion af industri. En udpræget forlagsindustri uden arbejdsdeling i selve produktionen var således den vestslesvigske kniplingsfremstilling, hvor kniplingshandleren forsynede de mange kniplepiger med råvarer i form af kniplingstråd, som pigerne så derhjemme forarbejdede til færdige kniplinger, der blev indsamlet af kniplingshandleren og af ham afsat på markedet. I andre tilfælde drejer det sig om manufakturer, hvor medarbejderne nok var samlet på ét sted og underlagt en vis arbejdsdeling, men hvor der kun var en meget begrænset anvendelse af maskiner. Dette gælder sandsynligvis nogle af de ældre spinderier, hvor motivet nok så meget synes at have været beskæftigelse og disciplinering af de fattige som produktionen i sig selv. ${ }^{9} \mathrm{Da}$ forlagsindustrien og manufakturerne må betragtes som protoindustri, d.v.s. som tilløb til en mere moderne industri, er de medtaget i de følgende opgørelser.

De her benyttede fabrikslister omfatter hertugdømmet Slesvig efter dettes afgrænsning fra for 1864. Erø og »de otte sogne« syd for Kolding samt det slesvigske territorium omkring Ribe er således medtaget, mens de kongerigske enklaver nordvest for Tønder og på vesterhavsøerne ikke indgår. Til sidst skal der dog bringes et par oplysninger om enklavernes industri.

\section{Antallet af industrivirksomheder og industriarbejdere}

I tabel 1 opgøres antallet af industrivirksomheder med seks eller flere ansatte. Opdelingen $\mathrm{i}$ brancher og fabrikstyper følger så vidt muligt Leif Hansen Nielsens opstilling. ${ }^{10}$ Virksomheder, der griber over flere brancher, placeres i den, der nævnes først. Tabellen viser, at der efter en lang tid med stagnation skete en betydelig vækst $i$ antallet af industrivirksomheder $\mathrm{i}$ de to årtier mellem $1837 \mathrm{og} 1857$. Derefter satte en vis tilbagegang ind. Omtrent halvdelen af industrivirksomhederne var teglværker. 
Tabel 1. Antal industrivirksomheder

\begin{tabular}{|c|c|c|c|c|c|c|c|}
\hline Branche og fabrikstype & 1811 & 1830 & 1837 & 1845 & 1851 & 1857 & 1863 \\
\hline $\begin{array}{l}\text { Sten-, jord- og glasindustri } \\
\text { Teglværker og kalkbrænderier } \\
\text { (ofte begge dele) }\end{array}$ & 17 & 39 & 45 & 61 & 73 & 143 & 110 \\
\hline Glasfabrikker & - & 2 & 2 & 4 & 5 & 4 & 3 \\
\hline $\begin{array}{l}\text { Spejlsliberi, sodafabrik, teglværk, } \\
\text { træsliberi* }\end{array}$ & - & - & - & - & 1 & 1 & 1 \\
\hline Fajancefabrikker og pottemagerier & 1 & - & - & - & - & - & 1 \\
\hline $\begin{array}{l}\text { Metalindustri } \\
\text { Jernstøberier og maskinfabrikker }\end{array}$ & - & 1 & 1 & 4 & 6 & 12 & 15 \\
\hline Kobber- og messingfabrikker & 1 & 1 & 1 & 1 & 1 & 1 & 1 \\
\hline Nagel- og skruefabrikker & - & - & - & - & 3 & 1 & 1 \\
\hline Vognfabrikker & - & 1 & 1 & - & - & - & - \\
\hline $\begin{array}{l}\text { Kemisk industri } \\
\text { Tændstikfabrikker }\end{array}$ & - & - & - & - & - & 5 & 4 \\
\hline Oliemøller & 2 & 2 & 2 & 3 & 8 & 10 & 7 \\
\hline Saltsyderier & - & - & 2 & 3 & 1 & 2 & 1 \\
\hline Amidamfabrikker (stivelsesfabrikker) & - & - & - & 1 & - & 1 & - \\
\hline Lys- og sæbefabrikker & 1 & 1 & 1 & 2 & - & - & - \\
\hline Tekstilindustri & & & & & & & \\
\hline Farverier & 1 & 1 & 1 & 1 & $\overline{-}$ & 1 & $\bar{z}$ \\
\hline Hørfabrikker & 2 & - & - & 1 & 2 & 5 & 5 \\
\hline $\begin{array}{l}\text { Spinde-/karterier, kradsuld- og } \\
\text { uldtøjsfabrikker }\end{array}$ & 5 & 4 & 2 & 2 & 5 & 9 & 1 \\
\hline Væverier og klædefabrikker & 3 & 1 & 1 & 8 & 4 & 10 & 7 \\
\hline $\begin{array}{l}\text { Hårdugs-, voksdugs-, } \\
\text { posamentfabrikker }\end{array}$ & - & - & - & - & 2 & 3 & 1 \\
\hline Kniplingsfabrikanter & 14 & 2 & 1 & 1 & 1 & 1 & - \\
\hline Papir- og læderindustri & & & & & & & \\
\hline Papirfabrikker & 2 & 2 & 1 & 2 & 3 & 3 & 5 \\
\hline Tapetfabrikker & - & - & - & - & - & 2 & 1 \\
\hline Garverier og læderfabrikker & 1 & 3 & 3 & 3 & 3 & 2 & 5 \\
\hline Handskefabrikker & - & 1 & - & - & - & - & - \\
\hline Træindustri & & & & & & & \\
\hline elfabrikker & 1 & 1 & 1 & - & - & - & - \\
\hline Hjulmagerier & 1 & - & - & - & - & - & - \\
\hline Savværk & - & - & - & - & - & - & 1 \\
\hline
\end{tabular}


Tabel 1 fortsat

\begin{tabular}{|l|r|r|r|r|r|r|r|}
\hline Branche og fabrikstype & 1811 & 1830 & 1837 & 1845 & 1851 & 1857 & 1863 \\
\hline Nærings- og nydelsesmiddelindustri & & & & & & & \\
Damp-, vand- og vindmøller & 1 & - & - & 3 & 1 & 3 & 5 \\
Slagterier & - & - & - & - & 1 & 2 & - \\
Ølbryggerier & - & - & - & - & - & 1 & 2 \\
Brændevinsbrænderier & - & - & - & 1 & 6 & 6 & 7 \\
Sukkerraffinaderier & - & 8 & 3 & 8 & 6 & 3 & - \\
Cikoriefabrikker & - & 2 & 1 & 1 & 1 & 2 & 1 \\
(kaffeerstatningsfabrikker) & 3 & 3 & 5 & 18 & 20 & 22 & 23 \\
Tobaks- og cigarfabrikker & & & & & & & \\
Andre industrier & - & - & - & - & - & 1 & - \\
Korkfabrikker & - & 1 & - & - & - & - & - \\
Rebslagerier & 56 & 76 & 74 & 128 & 153 & 256 & 208 \\
\hline Industrivirksomheder i alt & & & & & \\
\hline
\end{tabular}

* Christiansdal ved Haderslev.

I tabel 2 bringes efter den samme branche- og typeopdeling tal på det samlede antal arbejdere i virksomhederne. Hvor der i listerne er angivet et interval for beskæftigelsen, f.eks. 20-25, angives gennemsnitstallet, i eksemplet 221/2, afrundet til 23. Derved foregives en nøjagtighed, der ikke helt er hold for i virkeligheden. Spændvidden i intervallerne er dog aldrig mere end 10, og problemet er derfor overskueligt. Alvorligere er det, at flere erhverv havde udpræget sæsonbeskæftigelse. Det gælder først og fremmest den store teglværksindustri, men f.eks. også hør- og cikoriefabrikkerne. De tal, der anføres i listerne, er efter alt at dømme beskæftigelsen i sæsonen, og antallet af arbejdere har været markant lavere udenfor denne. En korrektion herfor i form af en omregning til antal "helårsarbejdere« er ikke mulig, da sæsonens længde afhang af vind og vejr og kunne afkortes eller strækkes alt efter ordrebeholdningen. I sammenligning med andre fabrikstyper med en mere stabil beskæftigelse hen over året som f.eks. jernstøberierne kommer teglværkerne derfor let til at veje tungere end i virkelighedens verden. Da teglværkerne udgjorde en meget stor del af den samlede slesvigske industri, fører sæsonudsvingene i teglfremstillingen til en ikke ringe grad af usikkerhed i de totale tal for hertugdømmets fabriksvæsen.

Ved travlhed i teglværksindustrien kunne kvinder og børn fungere som en arbejdskraftreserve. I andre brancher og fabrikstyper var børnearbejdet et permanent fænomen. Det gælder især i den betydelige 


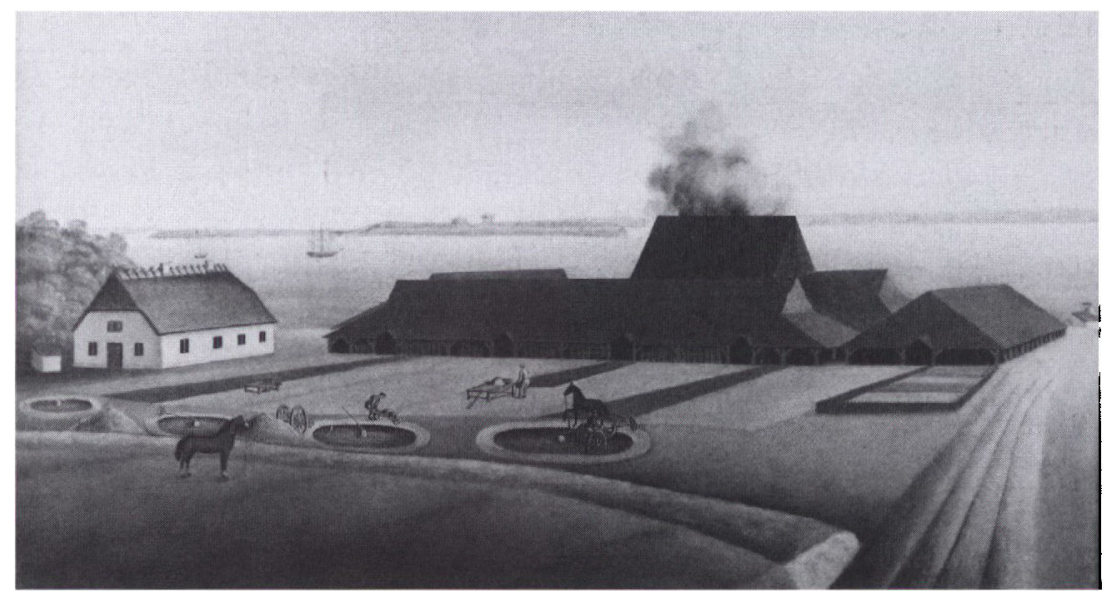

Målt efter det antal medarbejdere, som blev angivet $i$ fabrikslisterne, var teglindustrien ubestridt hertugdommet Slesvigs storste branche. Pa højden $i 1857$ beskxftigede den over 2.100 mand. Tallene angiver imidlertid beskæftigelsen $i$ sæsonen - om vinteren var teglværksarbejderne oftest arbejdslose. Billedet viser Cathrinesminde teglvark ved Mølmark på Broagerland omkring 1860. Som det ses, var mekaniseringen endnu ikke fremskreden her, idet leret blev æaltet ved hestekraft. Endvidere ses tørreladerne og ounbygningen. Foto på Museum Sonderjylland - Sønderborg Slot efter maleri $i$ privateje.

slesvigske tobaksindustri. Fabrikslisterne specificerer oftest arbejdskraften på de forskellige kategorier af arbejdere, daglejere, kvinder og børn, og det fremgår heraf, at børn nemt kunne udgøre halvdelen af arbejdsstyrken ved tobaksfremstillingen. Andre fabrikker med meget børnearbejde var cikorie- og tændstikfabrikkerne og i et mindre omfang nogle af klædefabrikkerne. I tabellen er alle medarbejdere talt som én beskæftiget, uanset at børnene formentlig ofte »kun« har arbejdet en halv dag. Ved branchesammenligninger fører dette til en vis skævhed f.eks. i forhold til jernstøberierne, der aldeles overvejende beskæftigede voksne mænd.

De fleste fabrikstyper benyttede daglejere som en arbejdskraft, der kunne tilkaldes og sendes bort efter virksomhedens øjeblikkelige behov. Også de er her talt som én arbejder, selv om de ikke har været fast beskæftiget i fabrikkerne. Listerne oplyser kun undtagelsesvis, hvor mange dage, de har været antaget, så en omregning til helårsarbejdere er også umulig her.

Samlet betyder de nævnte forbehold, at tabellens total for arbejdere i den slesvigske industri repræsenterer et noget overdrevet billede af 
industribeskæftigelsen - i hvert fald for de fabrikker, som indgår i opgørelserne; som nævnt er listerne ikke komplette, hvilket trækker i modsat retning. Den betydelige usikkerhed, som tallene således er behæftet med, betyder, at beskæftigelsen som helhed og i hvert fald $i$ teglværksindustrien rettelig bør angives som omtrentlige tal rundet ned til hele hundreder.

Tabel 2. Antal industriarbejdere

\begin{tabular}{|c|c|c|c|c|c|c|c|}
\hline Branche og fabrikstype & 1811 & 1830 & 1837 & 1845 & 1851 & 1857 & 1863 \\
\hline $\begin{array}{l}\text { Sten-, jord- og glasindustri } \\
\text { Teglværker og kalkbrænderier } \\
\text { (ofte begge dele) }\end{array}$ & 135 & 588 & 680 & 884 & 1114 & 2177 & 1640 \\
\hline Glasfabrikker & - & 53 & 81 & 108 & 143 & 126 & 151 \\
\hline $\begin{array}{l}\text { Spejlsliberi, sodafabrik, teglværk, } \\
\text { træsliberi }\end{array}$ & - & - & - & - & 6 & 50 & 30 \\
\hline Fajancefabrikker og pottemagerier & 7 & - & - & - & - & - & 6 \\
\hline Metalindustri & - & 98 & 125 & 386 & 648 & 998 & 837 \\
\hline fabrikker & 60 & 54 & 44 & 44 & 30 & 38 & 60 \\
\hline $\mathrm{Nag}$ & - & - & - & - & 41 & 6 & 24 \\
\hline Vognfabrikker & - & 20 & 32 & - & - & - & - \\
\hline Kemisk industri & & & & & & & \\
\hline Tænd & - & - & - & - & - & 161 & 125 \\
\hline $\begin{array}{l}\text { Oliemøller (adskillige tillige } \\
\text { kornmøller) }\end{array}$ & 13 & 33 & 24 & 52 & 118 & 113 & 60 \\
\hline Saltsyderier & - & - & 14 & 24 & 9 & 17 & 6 \\
\hline Amidamfabrikker (stivelsesfabrikker) & - & - & - & 6 & - & 11 & - \\
\hline Lys- og sæbefabrikker & 11 & 6 & 6 & 12 & - & - & - \\
\hline Tekstilindustri & & & & & & & \\
\hline & 20 & 11 & 12 & 13 & - & 14 & - \\
\hline Hørfabrikker & 43 & & - & 22 & 50 & 66 & 74 \\
\hline $\begin{array}{l}\text { Spinde-/ karterier, kradsulds- og } \\
\text { uldtøjfabrikker }\end{array}$ & 172 & 144 & 121 & 49 & 94 & 128 & 6 \\
\hline Væverier og klædefabrikker & 27 & 6 & 7 & 99 & 78 & 178 & 109 \\
\hline $\begin{array}{l}\text { Hårdugs-, voksdugs-, } \\
\text { posamentfabrikker }\end{array}$ & - & - & - & - & 24 & 37 & 12 \\
\hline Kniplingsfabrikanter & 1060 & 260 & 500 & 250 & 70 & 80 & - \\
\hline Papir- og læderindustri & & & & & & & \\
\hline & 17 & 17 & 13 & 32 & 121 & 178 & 123 \\
\hline er & -1 & -1 & -1 & - & - & 32 & 16 \\
\hline og læderfabrikker & 6 & 33 & 22 & 57 & 38 & 58 & 106 \\
\hline Handskefabrikker & & 59 & & - & & & \\
\hline
\end{tabular}


Tabel 2 fortsat

\begin{tabular}{|l|r|r|r|r|r|r|r|}
\hline Branche og fabrikstype & 1811 & 1830 & 1837 & 1845 & 1851 & 1857 & 1863 \\
\hline Træindustri & 16 & 12 & 10 & - & - & - & - \\
Møbelfabrikker & 12 & - & - & - & - & - & - \\
Hjulmagerier & - & - & - & - & - & - & 10 \\
Savværker & & & & & & & \\
Nærings- og nydelsesmiddelindustri & 6 & - & - & 29 & 6 & 23 & 47 \\
Damp-, vand- og vindmøller & - & - & - & - & 10 & 20 & - \\
Slagterier & - & - & - & - & - & 6 & 21 \\
Ølbryggerier & - & - & - & 11 & 46 & 48 & 78 \\
Brændevinsbrænderier & - & 58 & 21 & 76 & 50 & 27 & - \\
Sukkerraffinaderier & - & 27 & 10 & 10 & 12 & 26 & 12 \\
Cikoriefabrikker & & & & & & & \\
(kaffeerstatningsfabrikker) & 25 & 27 & 89 & 359 & 554 & 655 & 609 \\
Tobaks- og cigarfabrikker & & & & & & & \\
Andre industrier & - & - & - & - & - & 8 & - \\
Korkfabrikker & - & 19 & - & - & - & - & - \\
Rebslagerier & 1630 & 1525 & 1811 & 2523 & 3262 & 5281 & 4162 \\
\hline Industriarbejdere i alt & 1600 & 1500 & 1800 & 2500 & 3200 & 5200 & 4100 \\
\hline Omtrentlige, afrundede tal & \multicolumn{3}{|l}{} \\
\hline
\end{tabular}

Tabel 3 viser »top ti« over hertugdømmets største virksomheder, med datidens brede definition af industri og uanset arten af beskæftigede. Tabellen viser, hvorledes traditionelle forlagsvirksomheder og manufakturer veg til fordel for moderne fabrikker i toppen af den slesvigske industri.

Tabel 3. De ti største virksomheder målt $i$ medarbejderantal

\begin{tabular}{|l|l|l|l|l|l|}
\hline Nr. & 1811 & 1830 & 1845 & 1857 & 1863 \\
\hline 1 & $\begin{array}{l}\text { Hanquist, } \\
\text { Tønder, 200 } \\
\text { kniplepiger }\end{array}$ & $\begin{array}{l}\text { Hanquist, } \\
\text { Tønder, 250 } \\
\text { kniplepiger }\end{array}$ & $\begin{array}{l}\text { Hanquist, } \\
\text { Tønder, 250 } \\
\text { kniplepiger }\end{array}$ & $\begin{array}{l}\text { Carlshütte, } \\
\text { jernstøberi, } \\
588\end{array}$ & $\begin{array}{l}\text { Carlshütte, } \\
\text { jernstøberi, } \\
487\end{array}$ \\
\hline 2 & $\begin{array}{l}\text { Hansen, } \\
\text { Tønder, 200 } \\
\text { kniplepiger }\end{array}$ & $\begin{array}{l}\text { Carlshütte, } \\
\text { jernstøberi, 98 }\end{array}$ & $\begin{array}{l}\text { Carlshütte, } \\
\text { jernstøberi, 250 }\end{array}$ & $\begin{array}{l}\text { Walther, } \\
\text { Flensborg, } \\
\text { papirfabrik, 160 }\end{array}$ & $\begin{array}{l}\text { Dithmer, } \\
\text { Rendbjerg, } \\
\text { teglværk, 120 }\end{array}$ \\
\hline 3 & $\begin{array}{l}\text { Jensen, Tønder, } \\
100 \text { kniplepiger }\end{array}$ & $\begin{array}{l}\text { Altstädter Ar- } \\
\text { menkollegium } \\
\text { Slesvig, } \\
\text { spinderi, 72 }\end{array}$ & $\begin{array}{l}\text { Christiansfeld, } \\
\text { menigheden, } \\
\text { tobaksfabrik, } \\
76\end{array}$ & $\begin{array}{l}\text { Dithmer, } \\
\text { Rendbjerg, } \\
\text { teglværk, 120 }\end{array}$ & $\begin{array}{l}\text { Spielwerg } \\
\& \text { Co., } \\
\text { Christians- } \\
\text { feld, tobaks- } \\
\text { fabrik, 100 }\end{array}$ \\
\hline
\end{tabular}


Tabel 3 fortsat

\begin{tabular}{|c|c|c|c|c|c|}
\hline $\mathrm{Nr}$. & 1811 & 1830 & 1845 & 1857 & 1863 \\
\hline 4 & $\begin{array}{l}\text { Hertug af } \\
\text { Augustenborgs } \\
\text { spinderi i } \\
\text { Gråsten, } 72 \\
\text { spindersker }\end{array}$ & $\begin{array}{l}\text { Hansen, } \\
\text { Aabenraa, } \\
\text { handskefabrik, } \\
59\end{array}$ & \begin{tabular}{|l} 
Dittmann \& \\
Jensen, \\
Flensborg, \\
jernstøberi, 70
\end{tabular} & $\begin{array}{l}\text { Hinze, Slesvig, } \\
\text { tændstikfabrik, } \\
112\end{array}$ & $\begin{array}{l}\text { A. Jensen jr., } \\
\text { Flensborg, } \\
\text { glasfabrik, } 97\end{array}$ \\
\hline \multirow[t]{2}{*}{5} & \multirow[t]{2}{*}{$\begin{array}{l}\text { Kobbermallen, } \\
60\end{array}$} & \multirow[t]{2}{*}{$\begin{array}{l}\text { Dithmer, } \\
\text { Rendbjerg, } \\
\text { teglværk, } 55\end{array}$} & \multirow[t]{2}{*}{$\begin{array}{l}\text { Dithmer, } \\
\text { Rendbjerg, } \\
\text { teglværk, } 70\end{array}$} & \multirow[t]{2}{*}{$\begin{array}{l}\text { Ohlsen, } \\
\text { Flensborg, } \\
\text { tobaksfabrik, } \\
110\end{array}$} & $\begin{array}{l}\text { Ohlsen, } \\
\text { Flensborg, } \\
\text { tobaksfabrik, } \\
90\end{array}$ \\
\hline & & & & & $\begin{array}{l}\text { J.P. Schmidt } \\
\text { jr., Flensborg, } \\
\text { tobaksfabrik, } \\
90\end{array}$ \\
\hline 6 & $\begin{array}{l}\text { Flensborg bys } \\
\text { spinderi, } 45\end{array}$ & $\begin{array}{l}\text { Kobbermallen, } \\
54\end{array}$ & $\begin{array}{l}\text { Jacobsens enke, } \\
\text { Flensborg, } \\
\text { tobaksfabrik, } 50\end{array}$ & $\begin{array}{l}\text { Petersen \& } \\
\text { Bonnichsen, } \\
\text { Haderslev, } \\
\text { jernstøberi, } 104\end{array}$ & $\begin{array}{l}\text { C.F. Walther, } \\
\text { Flensborg, } \\
\text { papirfabrik, } \\
84\end{array}$ \\
\hline 7 & $\begin{array}{l}\text { Boysen, Højer, } \\
34 \text { kniplepiger }\end{array}$ & $\begin{array}{l}\text { Peter St. } \\
\text { Petersen, } \\
\text { Friedrichsfeld, } \\
\text { glasfabrik, 34 }\end{array}$ & $\begin{array}{l}\text { Spethmann, } \\
\text { Flensborg, } \\
\text { tobaksfabrik, } 49\end{array}$ & $\begin{array}{l}\text { Spielwerg } \\
\& \text { Co., tobaks- } \\
\text { fabrik, Chri- } \\
\text { stiansfeld, } 100\end{array}$ & $\begin{array}{l}\text { Witzke, } \\
\text { Flensborg, } \\
\text { tændstik- } \\
\text { fabrik, } 80\end{array}$ \\
\hline 8 & $\begin{array}{l}\text { IS i Tonder, } \\
34 \text { kniplepiger }\end{array}$ & $\begin{array}{l}\text { Schordan, } \\
\text { Christiansfeld, } \\
\text { uldspinderi, } 32\end{array}$ & \begin{tabular}{|l} 
J.P. Schmidt, \\
Flensborg, \\
tobaksfabrik, 48
\end{tabular} & $\begin{array}{l}\text { J.P. Schmidt, } \\
\text { Flensborg, } \\
\text { tobaksfabrik, } 95\end{array}$ & $\begin{array}{l}\text { Wiengreen \& } \\
\text { Firjahn, } \\
\text { Slesvig, læ- } \\
\text { derfabrik, } 75\end{array}$ \\
\hline 9 & $\begin{array}{l}\text { Møller, Tønder, } \\
50 \text { kniplepiger }\end{array}$ & $\begin{array}{l}\text { Heide, Iller, } \\
\text { teglværk, } 30\end{array}$ & \begin{tabular}{|l} 
Peter St. \\
Petersen, \\
Friedrichsfeld, \\
glasfabrik, 46
\end{tabular} & $\begin{array}{l}\text { Hanquist, } \\
\text { Tønder, } 80 \\
\text { kniplepiger }\end{array}$ & \begin{tabular}{|l|} 
Dittmann \& \\
Brix, \\
Flensborg, \\
jernstøberi, 70 \\
\end{tabular} \\
\hline 10 & $\begin{array}{l}\text { Tønder by, } \\
\text { uldhatte og } \\
\text {-strømper, } 30\end{array}$ & $\begin{array}{l}\text { Schlaikier, } \\
\text { Egernsund, } \\
\text { teglværk, } 28\end{array}$ & $\begin{array}{l}\text { Kobbermøllen, } \\
44\end{array}$ & \begin{tabular}{|l} 
Dittmann \& \\
Jensen, \\
Flensborg, \\
jernstøberi, 75
\end{tabular} & $\begin{array}{l}\text { H.C. Hansen, } \\
\text { Haderslev, } \\
\text { tobaksfabrik, } \\
67\end{array}$ \\
\hline
\end{tabular}


Endelig kan totaltallene fra tabel 1 og 2 grafisk fremstilles således:

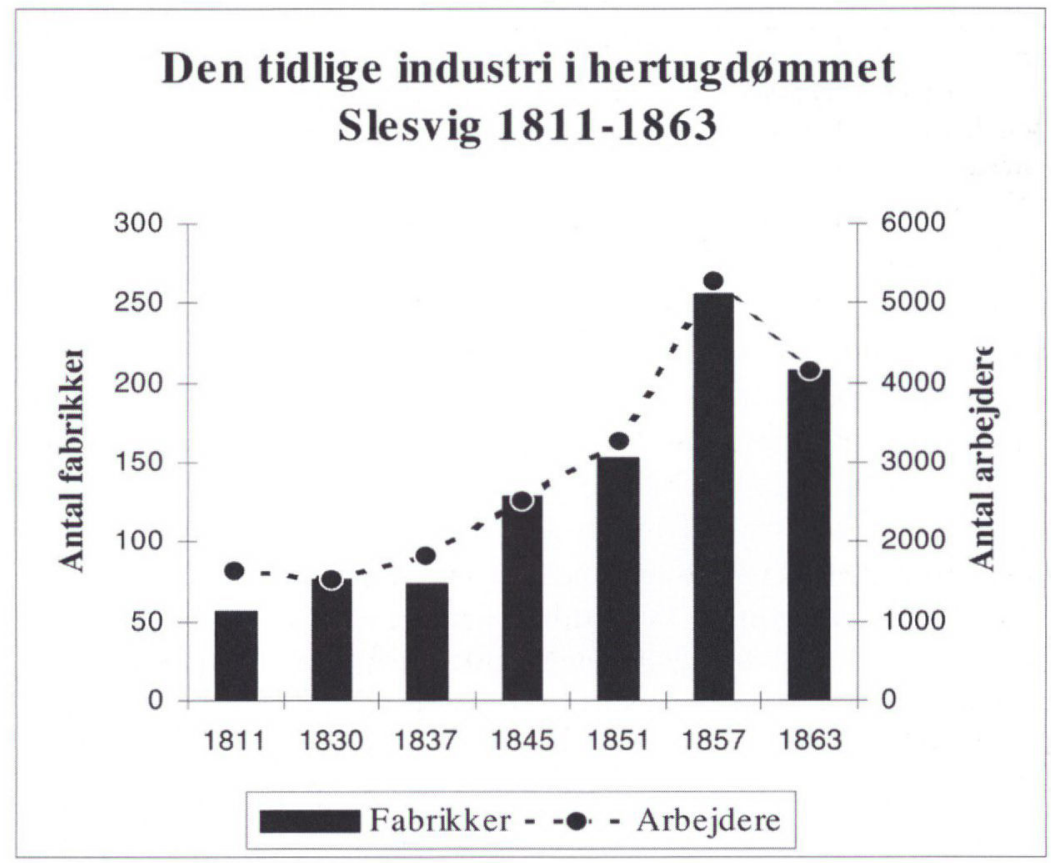

Diagrammet viser, at udviklingen i den slesvigske industri 1811-1863 overordnet set afspejlede det generelle konjunkturforløb i hertugdømmerne: Stagnation indtil 1830, derefter en betydelig vækst indtil 1857 , hvorefter en afmatning med en vis tilbagegang satte ind. ${ }^{11}$

\section{1-1830 - kvantitativ stagnation, men kvalitativ vækst}

I 1811 tilspidsedes de turbulente økonomiske forhold, som var en følge af det danske monarkis uheldige involvering i Napoleonskrigen siden 1807, til en egentlig krise. At 1811 var et kriseår, fremgår således direkte af fabrikslisten for dette år. Ved mange teglværker er beskæftigelsen "i gode tider « anført; denne lå 144 over det aktuelle niveau på 135. For Flensborgs vedkommende var der tale om en tilbagegang $i$ beskæftigelsen fra 137 i 1810 til 112. Den økonomiske krise fortsatte i det væsentligste frem til ca. 1830. Følgerne af statsbankerotten og 
valutasammenbruddet i 1813, flere dårlige høstår og landbrugskrisen 1819-25 prægede konjunkturerne $\mathrm{i}$ hertugdømmerne til midten af 1820 'erne. Først derefter begyndte en langsom fremgang. I hele perioden var den slesvigske industri - så vidt vi kan tillade os konklusioner ud fra de to isolerede talopgørelser fra 1811 og 1830 - præget af stagnation.

En nærmere betragtning af udviklingen indenfor de enkelte brancher afslører imidlertid store forandringer, hvor de gammeldags industrityper veg for mere moderne fabrikker. Først og fremmest ses dette af kniplingsproduktionens stærke tilbagegang mellem 1811 og 1830: Fra 14 til kun 2 fabrikanter og fra 1060 til blot 260 kniplepiger. Også manufakturer anlagt med henblik på at skabe beskæftigelse for fattige gik tilbage. I 1811 havde Flensborg by således et spinderi med 45 ansatte, og i Slesvig by havde fattigkollegiet i bydelen Friedrichsberg et hørspinderi med 25 spindere, mens Tønder by havde en fabrik med produktion af uldhatte og -strømper med 30 arbejdere. Hertugen af Augustenborg havde i Gråsten et spinderi med 72 spindersker, der var oprettet i 1787 som en spindeskole med et socialt sigte. ${ }^{12}$ I 1830 havde i Slesvig by Altstadts og Friedrichsbergs fattigkollegier henholdsvis 72 og 13 ansat $i$ deres spinderier, mens hertugen havde $27 \mathrm{i}$ sit i Gråsten. I 1837 figurerede ingen af de her nævnte socialt begrundede spinderier mere på fabrikslisten.

Blandt de traditionelle industrier var der til gengæld stor fremgang for teglfremstillingen, der godt og vel fordoblede antallet af virksomheder og mere end firedoblede antallet af arbejdere. Men der kom også nye fabrikker til. Ligesom teglværkerne var lokaliseret, hvor det gode ler var let tilgængeligt, blev der anlagt glasfabrikker ved Friedrichsfeld og Prinzenmoor nord for Rendsborg, hvor den tørv fandtes, som skulle levere brændsel til smeltningen. Her åbnedes fabrikker af Pederstamme-Petersen i 1811 og af Plöhn i 1824, som opnåede en pæn størrelse, mens en tredje fabrik grundlagt i 1822 af Heintze var ret ustabil og ikke med på fabrikslisten fra $1830 .{ }^{13}$ Nye virksomheder var desuden nogle sukkerraffinaderier og et par cikoriefabrikker, men først og fremmest indvarsledes den nye tid af en enkelt nygrundlagt fabrik: jernstøberiet Carlshütte ved Büdelsdorf nord for Rendsborg. Værket blev grundlagt i 1827 af tømmerhandler Marcus Hartwig Holler i Rendsborg. Det havde juridisk form af et aktieselskab, der hovedsagelig var ejet af Holler selv og hans familie og et par andre købmænd i Rendsborg, men også den kongelige statholder, prins Carl af 


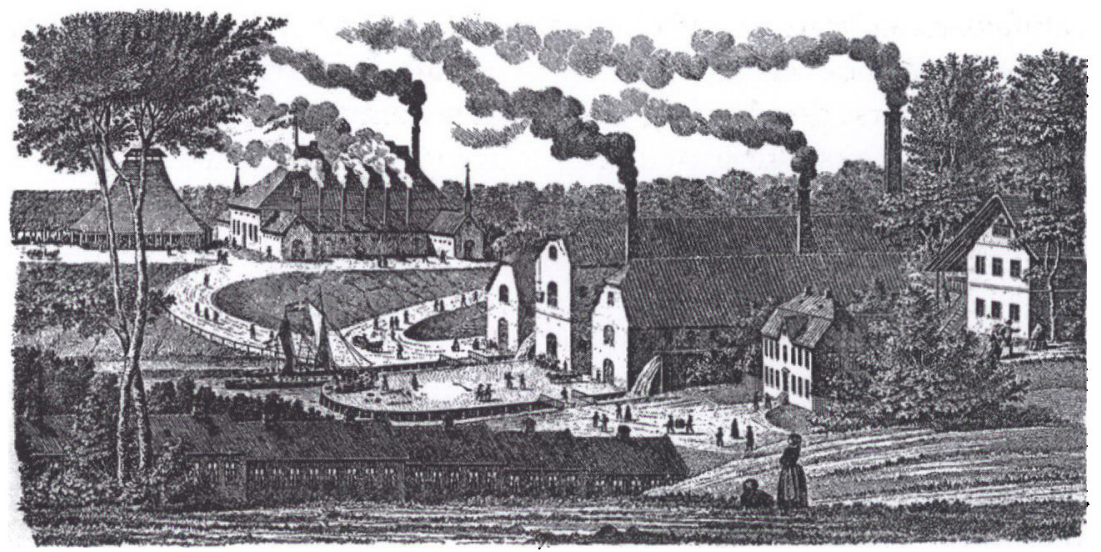

Et industrikonglomerat med mange op-og nedture var Christiansdal ved Hammelev. I tiden mellem de slesvigske krige, hworfra dette billede stammer (ca. 1856), produceredes her soda, spejle, almindeligt vinduesglas, træmasse, papir, teglsten m.m. Museum Sonderjylland - Institut for Sonderjysk Lokalhistorie.

Hessen var aktionær. Han gav navn til foretagendet og som beslægtet med kongehuset tillige protektion og glans. ${ }^{14}$ Allerede i 1830 var Carlshütte hertugdømmets næststørste virksomhed - efter en nutidig definition af industri den største - og frem til 1857 blev medarbejdertallet seksdoblet.

\section{0-1857 - den tidlige industrialisering tager fart}

Fra omkring 1830 kunne man anse krisen i hertugdømmernes erhvervsliv for overvundet. Derefter indledtes en periode med økonomisk vækst i de tre næste årtier, som klart aftegnes i det voksende antal af virksomheder og beskæftigede i den slesvigske industri, navnlig efter 1837. Treårskrigen $1848-50$ betød næppe nogen generel økonomisk tilbagegang, og den var i alle tilfælde hurtigt overvundet for den slesvigske industri. Her havde det en særlig betydning, at toldgrænsen fra august 1850 til juli 1853 lå langs Ejderen og skærmede af for konkurrencen fra den stærkere holstenske industri. ${ }^{15}$ De følgende år indtil 1857 gav et sandt boom for hertugdømmernes akonomi, som medførte en accelereret vækst i den slesvigske industri.

Carlshütte fik efter nogle år følgeskab af en række andre jernstøberier, som tilsammen blev den tidlige industrialiserings spydspids $i$ hertugdømmerne. Ganske vist fandtes de nødvendige råstoffer ikke 
her - Hollers forsøg med at udvinde jern af den hjemlige myremalm viste sig snart urentable - men der var ikke mindst $i$ landbruget og i husholdningerne et stigende behov for jernredskaber og -maskiner, som skabte et marked for talrige former for jernprodukter. I løbet af 1840 'erne og 1850'erne fik næsten alle købstæder og et par af flækkerne mindst ét jernstøberi. Foruden Carlshütte fik to af disse, Bonnichsens \& Petersens støberi i Haderslev og Dittmann \& Jensens $i$ Flensborg, plads blandt hertugdømmets 10 største fabrikker:

Tabel 4. Jernstøberier $i$ Slesvig med grundlæggelsesår og antal arbejdere ${ }^{16}$

\begin{tabular}{|l|l|c|c|}
\hline Sted & Grundlægger(e) & År & Arbejdere 1857 \\
\hline Büdelsdorf & Carlshütte (M.H. Holler) & 1827 & 588 \\
Haderslev & Josua Petersen \& A.P. Bonnichsen & 1841 & 104 \\
Flensborg & Nikolaus Jepsen & 1842 & 33 \\
Flensborg & Dittmann \& Jensen & 1842 & 75 \\
Haderslev & Wolfgang Petersen & 1847 & 60 \\
Sønderborg & Peter Petersen & 1850 & $25(1861)$ \\
Husum & J.F. Christiansen & 1852 & 28 \\
Aabenraa & A.T. Stallknecht & 1852 & 20 \\
Højer & Niels Petersen \& J.Th.H. Hansen & 1852 & 12 \\
Haderslev & Frederiks Støberi (I/S med 6 deltagere) & 1855 & 12 \\
Slesvig & H.C. Nagel & 1856 & 24 \\
Kappel & H.C. Claussen & 1856 & 20 \\
Sønderborg & J.A. Detlefsen \& B. Stein & 1857 & 22 \\
Tønder & Nis P. Lorenzen & 1857 & $18(1861)$ \\
\hline
\end{tabular}

Da jernindustrien allerede er fyldigt behandlet af Gerd Vaagt og Lars N. Henningsen, skal der ikke her gås dybere ind i denne branche, der på sin højde i 1857 beskæftigede ca. 1000 medarbejdere og indtog pladsen som Slesvigs andenstørste industri. ${ }^{17}$ Til metalindustrien hørte også kobber- og messingfabrikationen, som Kobbermøllen ved Flensborg var ene om at repræsentere. Målt ud fra antallet af medarbejdere prægedes Kobbermøllen af tilbagegang frem til 1851, hvorefter en fornyet vækst satte ind, så den i 1863 var tilbage til udgangspunktet i 1811 med 60 arbejdere. De øvrige dele af metalindustrien, nagel- og skruefabrikker samt vognfabrikker, besad kun en ringe grad af kontinuitet.

Teglfabrikationen forblev gennem hele perioden den største branche i den slesvigske industri-også selvom dens medarbejdertal som nævnt sandsynligvis kun gjaldt for sæsonen. Fra 1830 til 1857 blev beskæfti- 
gelsen her stærkt forøget $i$ takt med velstandsudviklingen, som for en stor del blev omsat i et betydeligt nybyggeri af stuehuse, stalde og lader indenfor landbruget samt beboelseshuse i byerne. De største teglværker fandtes gennem hele perioden i Nybøl herred, hvor der var nem adgang både til rigelige råstofmængder og afsætning af de tunge produkter ad søvejen, men væksten skete ikke mindst ved en spredning af teglindustrien ud over hele hertugdømmet, forudsat der på stedet var ler til rådighed. Alene Dithmers teglværk Rendbjerg ved Egernsund hørte til bland hertugdømmets 10 største fabrikker i 1830, 1845 og 1857. Det, som gav teglværksindustrien i Nybøl herred dens styrke, var nok så meget de mange mellemstore værker. I 1857 havde her 17 teglværker 10-19 arbejdere, mens 13 havde 20-29, 3 30-39, 2 40-49 og et enkelt Dithmers - 120. En tilsvarende mellemstørrelse havde de fleste andre værker omkring Flensborg fjord, mens de andre steder i hertugdømmet ofte var noget mindre.

Til sten-, jord- og glasindustrien hørte også glasfabrikkerne, som også ekspanderede. I moseområdet nord for Rendsborg anlagdes yderligere et par glasfabrikker, tildels ud fra de eksisterende, og i Flensborg grundlagde Stahnke \& Jensen i 1852 en glasfabrik, der i 1863 havde 97 medarbejdere. Et spejlsliberi fandtes på Christiansdal ved Hammelev, hvor der også var en sodafabrik, et teglværk og et træsliberi. Fabrikskonglomeratet var længe ret småt kørende målt ud fra antallet af medarbejdere, men var i en noget ustabil fremgang efter 1850 , hvor brødrene Weber overtog driften. ${ }^{18}$

Velstandsstigningen betød også et øget forbrug af nydelsesmidler og var således drivkraften i den stærke vækst, som kendetegnede den tredjestørste industrigren i Slesvig, tobaksfremstillingen. Tobaksfabrikkerne fandtes især i købstæderne; enhver købstad med nogenlunde respekt for sig selv havde mindst én tobaksfabrik. De største tobaksfabrikker var i 1857 C.F. Ohlsen i Flensborg med 110 ansatte, Spielwerg \& Co. i Christiansfeld med 100, J.P. Schmidt jr. i Flensborg med 95, F.D. Spethmann i Egernførde med 72, Nic. Nielsen i Flensborg med 63, H.C. Hansen i Haderslev med 49 og H.W. Marxen i Slesvig med 26 . Resten havde under 20 ansatte. Imidlertid betød som nævnt børne- og kvindearbejdet meget i tobaksfabrikationen. Spielwerg \& Co. og F.D. Spethmann havde f.eks. hver 50 drenge, H.C. Hansen 28 drenge foruden 10 kvinder. Formentlig udgjorde børn tæt ved halvdelen af tobaksfabrikkernes arbejdsstyrke.

For tekstilbranchens vedkommende er billedet temmelig sammen- 


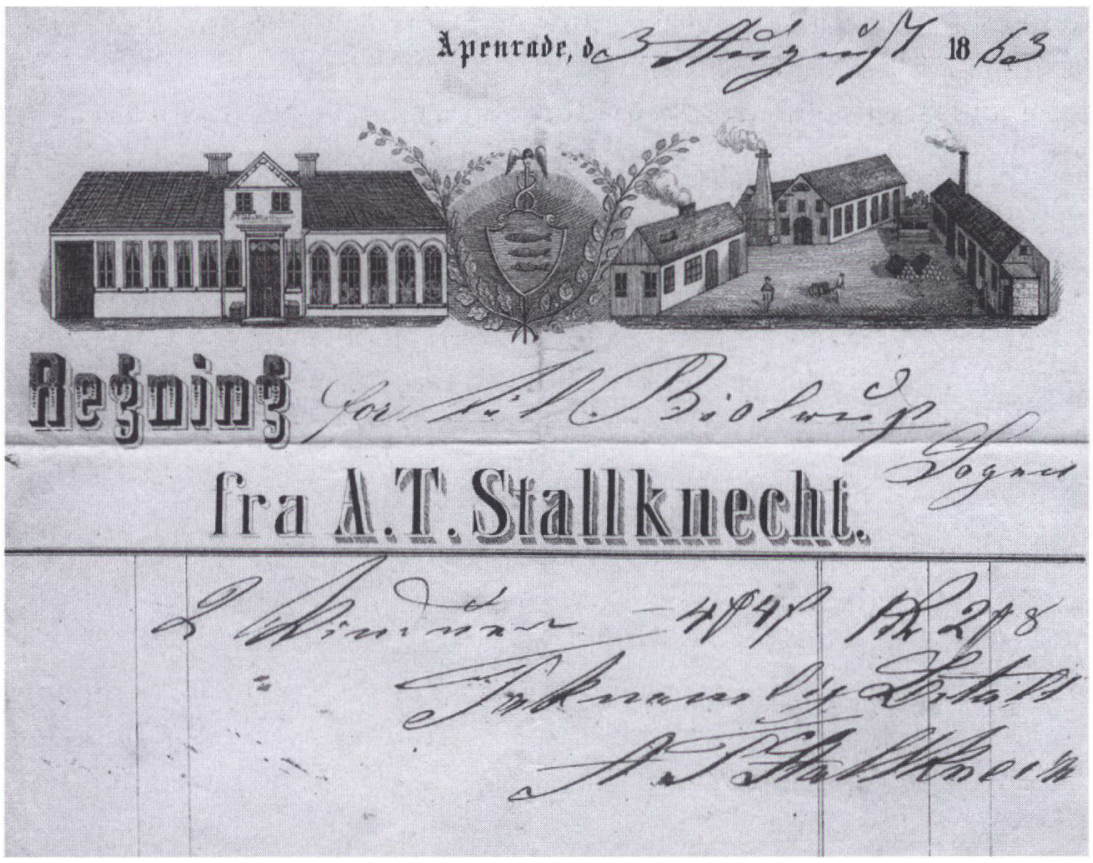

Som de andre købstæder fik også Aabenraa sit jernstøberi. Det skete $i$ 1852, da A.T. Stallknecht grundlagde sit støberi i Slotsgade. På regningen fra 1863 på to støbejernsvinduer ses til venstre det endnu eksisterende forhus med fabrikkens egne jernvinduer, $i$ midten Aabenraas byvaben og til højre fabriksbygningerne, der til dels endnu er bevaret. Museum Sønderjylland - Institut for Sønderjysk Lokalhistorie.

sat. Kniplingsfabrikationen fortsatte sin tilbagegang, som ved periodens slutning nærmest var fuldbyrdet til forsvinden. Johan og O.C. Hanquist i Tønder holdt længst ud. For hørfabrikker og spinderier, karterier, kradsulds- og uldtøjsfabrikker er billedet noget sløret; en nedgang $\mathrm{i}$ begyndelsen af perioden synes afløst af fremgang $i$ 1850 'erne. Blandt de større spinderier var Ths. Tychsen Hansens bomuldsspinderi i Tønder med 36 ansatte i 1857. Den samme tendens gælder for klædefabrikker og væverier, hvor væksten dog synes større. Der var imidlertid ingen, som blev særlig store - konkurrencen fra den stærke holstenske tekstilindustri i Neumünster syntes at have været for stærk. I Egernførde fandtes W.A. Mortensens stoutsvæveri med 36 medarbejdere i 1850, i $1857 \mathrm{Hs}$. Chr. Langes Söhnes væveri med 28 og H.W. Mundus' klædefabrik med 24 ansatte. I Frederiksstad havde Wiesenfeldts væveri i 185736 medarbejdere, mens i Slesvig 
Schultz' og Schmidts væveri samme år havde 26 og Sehlmachers klædefabrik 21. I Flensborg havde C.W. Krackes klædefabrik i 184526 arbejdere. Resten havde under 20 ansatte, således alle i Nordslesvig, hvor dog Peter Nissens klædefabrik i Rens og A. Schaus i Sønderborg havde 10 eller derover i deres brød. Farverierne var nærmest uden industriel betydning.

Blandt læder- og papirfabrikkerne opnåede af de førstnævnte alene Wiengreen \& Firjahns garveri i Slesvig en nævneværdig størrelse (52 medarbejdere i 1857). Af større og voksende betydning var den slesvigske papirfabrikation. De to gamle fabrikker i Ascheffel og Flensborg blev i begyndelsen af 1800-tallet begge drevet af familien Walther. Møllen i Ascheffel gik dog i 1837 efter en konkurs over i Wilh. Robberts eje. Mens sidstnæunte aldrig voksede sig særlig stor, ekspanderede fabrikken i Flensborg kraftigt efter 1845 for i 1856/57 at være hertugdømmets næststørste industrivirksomhed (18 medarbejdere i 1845, 100 i 1853, 160 i 1856). Langt nyere og mindre var J.J. Zieglers papirmølle i Fredsted ved Haderslev, hvor der i 1850 'erne var en 8-9 ansatte. Til papirbranchen hørte endvidere i 1857 to tapetfabrikker i Flensborg med 10 og 22 arbejdere.

I den kemiske industri fik oliemøller og tændstikfabrikker efterhånden en vis betydning. I 1857 var der seks oliemøller i Flensborg, to i Sønderborg, en i Frederikstad og en på landet ved Lundsgård Vesterskov i Flensborg amt. Flest - nemlig 27 - beskæftigede F.N. Friedrichsen i Flensborg. Tændstikfabrikkerne fandtes hovedsagelig i Slesvig by, hvor den største af de i alt fire var Hinzes med 112 ansatte i 1857 og en plads som hertugdømmets fjerdestørste fabrik.

\section{7-1863 - stagnation og tilbagegang}

Toppunktet for den tidlige industrialisering af hertugdømmet Slesvig blev nået $\mathrm{i}$ 1857. Dette år ramte den internationale krise hertugdømmernes handel og industri, mens landbruget mestendels blev forskånet. For den samlede slesvigske økonomi udgjorde krisen ikke nogen katastrofe, men betød en udvikling på et jævnere niveau i de følgende år. For industrien udmøntede krisen sig imidlertid i en mærkbar tilbagegang, som det fremgår af tallene for 1863. Måske var den næppe helt så stor i virkeligheden (jfr. ovenfor). I hvert fald lå tallene for året 1861 noget højere i de områder, hvorfra listen fra dette år er bevaret. ${ }^{19}$ Men den mulighed foreligger selvfølgelig også, at tilbagegangen er 
fortsat efter 1861. Under alle omstændigheder lå antallet af industrivirksomheder og de deri beskæftigede i 1863 stadig langt over tallene fra 1850'ernes begyndelse.

Tilbagegangen ramte alle de store brancher, især den altid konjunkturfølsomme teglfremstilling, tekstil og jern, mens tobak slap nådigt. Fremgang var der kun i glasfremstillingen, kobber- og messingfabrikation samt læderfabrikker; $i$ alle tre tilfælde takket være en enkelt virksomheds heldige udvikling (Stahnke \& Jensen i Flensborg, Kobbermøllen og Wiengreen \& Firjahn i Slesvig).

Der foreligger desværre ikke fabrikslister, som giver mulighed for at følge udviklingen efter krigen og hertugdømmernes afståelse til Østrig og Preussen 1864 og deres indlemmelse i sidstnævnte stat i 1867. Hertugdømmernes økonomi i almindelighed prægedes ikke så stærkt af krigen i 1864 i sig selv som af de stærkt forandrede forhold, overgangstiden og indlemmelsen i Preussen og siden i Det tyske Rige i 1870 førte med sig. Den nye dansk-tyske grænse blev også toldgrænse og afskar de slesvigske producenter fra deres traditionelle afsætning til Kongeriget. Først langsomt kunne disse forbindelser genetableres og aldrig blot tilnærmelsesvis i deres gamle omfang. Især den nordlige del og Flensborg led herunder, men i det hele taget skiftede Slesvig nu status fra at have været en forholdsvis industrielt udbygget del af det danske monarki til at være en tilbagestående landsdel i det store Tyskland. ${ }^{20}$ Der er adskillige vidnesbyrd om, at de forandrede forhold betød en voldsom rystelse for store dele af den slesvigske industri. I Flensborg ramtes navnlig tobaks- og sukkerfremstillingen hårdt og varigt, men også de andre brancher måtte notere tilbagegang. ${ }^{21}$ I Haderslev gik to ud af byens tre jernstøberier konkurs, og samme skæbne overgik fabrikkerne ved Christiansdal, mens M. Hansens tobaksfabrik alene overlevede ved at lægge om til udelukkende at producere skråtobak. ${ }^{22}$

For hele Slesvig foreligger der først nye fabrikslister fra 1876. De viste en tilbagegang i antallet af virksomheder fra 208 i 1863 til 53 og i antallet af arbejdere fra 4100 til knap 2700 (ekskl. skibsbyggeri). ${ }^{23}$ Med alle forbehold for eventuelle forskellige optagelseskriterier i den slesvigske og preussiske administrations industristatistik kan tallene kun udtrykke en stærk tilbagegang i forhold til tiden før 1864. De ændrede statsretslige forhold satte med andre ord den slesvigske industri i en helt ny og vanskeligere situation. 


\section{Industriens lokalisering 1830-1863}

I tabel 5 og 6 anføres den geografiske spredning af den slesvigske industri 1830-1863. Tabellerne viser industriens fordeling på Flensborg by, de øvrige købstæder og flækkerne, Nybøl herred med Broagerland i Sundeved og de øvrige landområder.

Tabel 5. Industriens lokalisering - absolutte tal

\begin{tabular}{|l|c|c|c|c|c|c|r|r|}
\hline \multirow{2}{*}{ Lokalisering } & \multicolumn{3}{|c|}{ Antal virksomheder } & \multicolumn{3}{c|}{ Antal medarbejdere } \\
\cline { 2 - 9 } & 1830 & 1845 & 1857 & 1863 & 1830 & 1845 & 1857 & 1863 \\
\hline Flensborg & 15 & 29 & 40 & 32 & 158 & 516 & 1009 & 897 \\
Øvrige købstæder* & 14 & 34 & 65 & 57 & 522 & 760 & 1297 & 1039 \\
$\quad$ samt flækker & & & & & & & & \\
Nybøl herred** & 19 & 24 & 37 & 32 & 379 & 509 & 866 & 755 \\
Øvrige landområder & 28 & 41 & 114 & 87 & 466 & 738 & 2109 & 1471 \\
\hline I alt & 76 & 128 & 256 & 208 & 1525 & 2523 & 5281 & 4162 \\
\hline
\end{tabular}

* Inkl. piger beskæftiget af kniplingskræmmere i Tønder (h.h.v. 2, 1, 1 og 0). Pigerne (h.h.v. 260, 250, 80 og 0) burde rettelig regnes under landdistrikterne, da de var bosat her.

** Udstrækning efter 1850.

Tabel 6. Industriens lokalisering - procent

\begin{tabular}{|l|c|c|c|c|c|c|c|c|}
\hline \multirow{2}{*}{ Lokalisering } & \multicolumn{3}{|c|}{ Antal virksomheder } & \multicolumn{3}{c|}{ Antal medarbejdere } \\
\cline { 2 - 9 } & 1830 & 1845 & 1857 & 1863 & 1830 & 1845 & 1857 & 1863 \\
\hline Flensborg & 20 & 23 & 16 & 15 & 10 & 20 & 19 & 22 \\
Øvrige købstæder & 18 & 27 & 25 & 27 & 34 & 30 & 25 & 25 \\
$\quad$ samt flækker & & & & & & & & \\
Nybøl herred & 25 & 19 & 14 & 15 & 25 & 20 & 16 & 18 \\
Øvrige landområder & 37 & 32 & 45 & 42 & 31 & 29 & 40 & 35 \\
\hline I alt & 100 & 100 & 100 & 100 & 100 & 100 & 100 & 100 \\
\hline
\end{tabular}

Flensborg by opnåede efter 1830 hurtigt status som hertugdømmernes dominerende industriby. Ganske vist faldt byens andel af virksomhederne, men andelen af medarbejderne lå ret fast omkring en femtedel af samtlige - et udtryk for, at byens fabrikker blev stadig større fra gennemsnitligt godt 10 medarbejdere i 1830 til 28 i 1863. De andre købstæder og flækker husede en faldende andel af medarbejderne, men tilsammen dog flere end Flensborg. Næst efter Flensborg fandtes de fleste industriarbejdere i 1857 i Slesvig by med 392, 


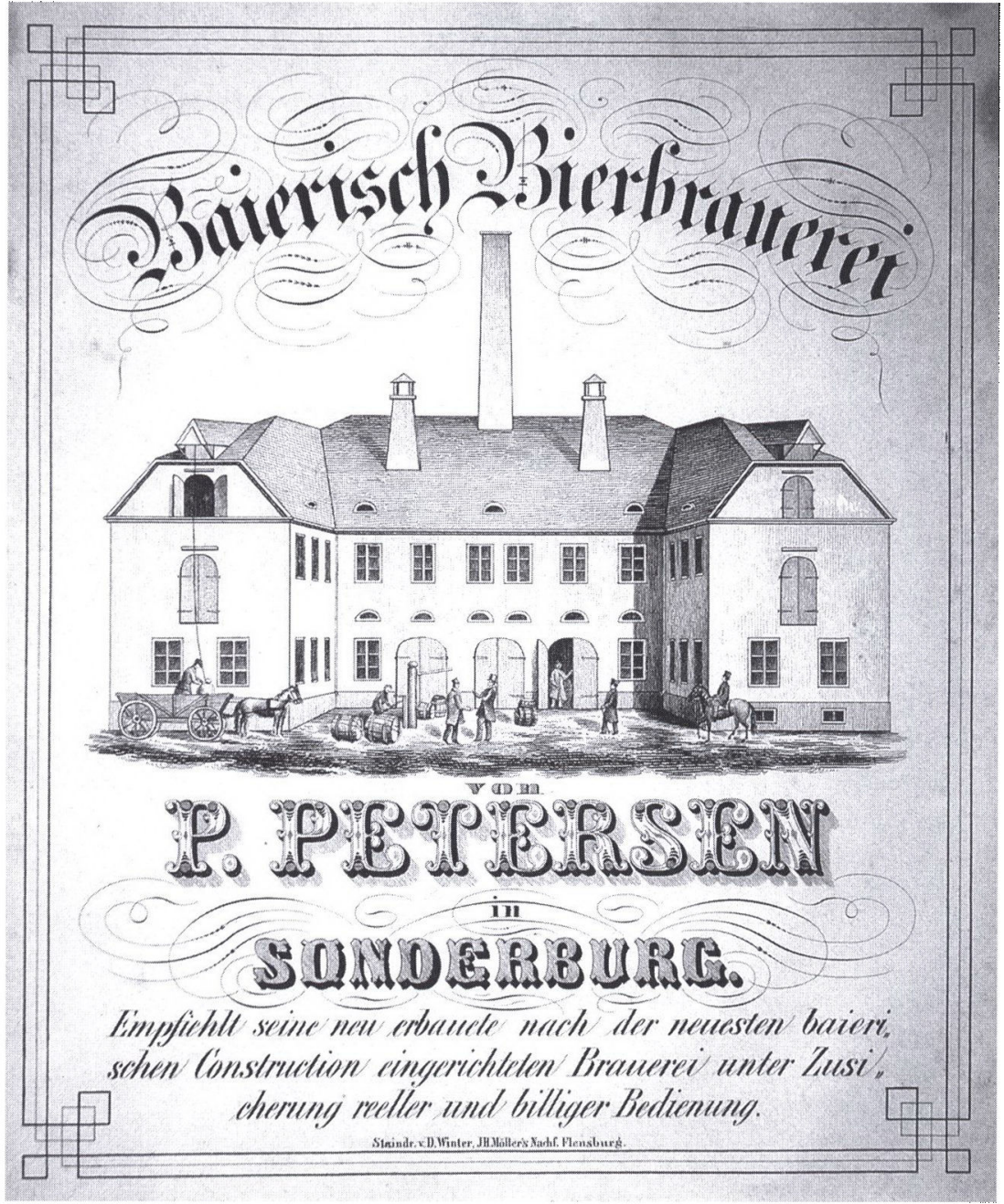

Peter Petersens albryggeri $i$ Sønderborg blev grundlagt $i$ 1853. Det var det eneste større bryggeri, som forekommer $i$ de slesvigske fabrikslister for 1864. Den store ekspansion $i$ denne branche skete forst efter 1864 - Fuglsangs bryggeri $i$ Haderslev er således fra 1865. Reklame for bajersk ol fra Sonderborg, formentlig fra bryggeriets første år. Museum Sønderjylland - Sønderborg Slot.

fulgt af Haderslev med 262, Tønder med 151 (heraf 80 ved kniplingsfremstilling) og Egernførde med 132. Resten havde under 100 - Aabenraa dog flere, når skibsværfterne tælles med (se nedenfor). Over halvdelen af den slesvigske industri var placeret i landområderne, 
med en særlig, om end faldende koncentration, i Nybøl herred, som var centrum for teglstensproduktionen. Men også en række andre virksomheder lå, $\mathrm{i}$ det mindste $\mathrm{i}$ administrativ henseende, udenfor købstæderne. I 1857 var det Carlshütte og Kobbermøllen, som dog begge lå i tilknytning til henholdsvis til Rendsborg og Flensborg, derudover glasfabrikkerne ved moserne i Hütten amt, papirfabrikkerne i Ascheffel og Fredsted, klædefabrikkerne i Rens og Læk, hørfabrikkerne i Broager, Lundsgård og Gettorf, dertil nogle møller samt fabrikkerne i Christiansdal. I flækkerne lå tobaksfabrikken i Christiansfeld samt jernstøberierne i Kappel og Højer. Både by og land havde dermed nydt godt af den tidlige industrialisering i Slesvig.

\section{Enklavernes industri}

I de kongerigske enklaver nordvest for Tønder eksisterede en betydelig tekstilindustri. I 1847 fandtes her tre kniplingskræmmere med ca. 650 kniplepiger, et håndstrikkeri med 80 arbejdere og et uld- og bomuldsvæveri i Brede tilhørende kniplingskræmmer Jens Wulff og sønner med 60 arbejdere. ${ }^{24}$ Dette væveri ekspanderede efter 1850 og havde 90 arbejdere i 1851 og 114 i 1855. En klædefabrik i Ballum havde i 18516 ansatte, men siden færre. Kniplingsindustrien talte i 1855 i sognene Ballum, Brede, Daler og Møgeltønder otte kniplingsfabrikanter med tilsammen 1195 kniplepiger. $^{25}$

\section{Skibsværfterne}

Som nævnt giver fabrikslisterne kun sporadiske oplysninger om det slesvigske skibsbyggeri. De skal dog anføres her for at give en fornemmelse for denne branches betydning i sammenligning med den ovenfor omtalte industri.

I 1837 nævner fabrikslisterne et lille skibsbyggeri i Frederikstad med 4-8 mand, to værfter i Aabenraa med henholdsvis 90-100 og 3040 mand samt et mindre værft i Kappel med 10-14 mand. I 1850 og 1851 nævner listerne alene Jørgen Bruhns skibsværft på Kalvø med henholdsvis 38 og 60 mand.

Først i 1856/57 giver listerne mulighed for et bredere vue over det slesvigske skibsbyggeri. Der var da i Nübbel ved Rendsborg fire værfter: Bocks med 7-8 ansatte, Detlef Sievers' med 12, Rohwers med 1416 og Peter Sievers' med ca. 30. Ved Rendsborgs Vorwerk fandtes 


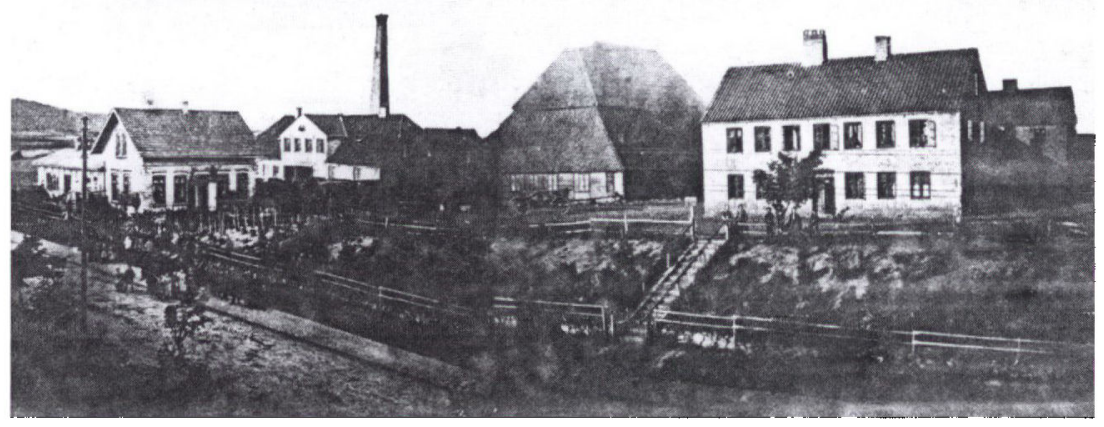

Blandt de fabrikker, som havde fremgang trods nedgangen $i$ konjunkturerne efter 1857, var Stahnke $\mathcal{E}$ Jensens glasfabrik $i$ Flensborg fra 1852, der $i 1863$ havde tat ved 100 medarbejdere. Her ses fabrikken fra Aabenraagade. Foto formentlig fra 1860 'erne på Museum Sonderjylland - Sanderborg Slot.

Paaps skibsbyggeri med 8 og Hartwig Holler \& Co.s værft med 58 mand. I alt var der således ved Ejderen seks værfter med 131 arbejdere (1861 var det øget til syv værfter med 137 arbejdere). I Egernførde fandtes $1856 / 57$ tre skibs- eller måske snarere bådebygningspladser, der beskæftigede i alt 10-20 mand. Arnæs havde to værfter tilhørende Johannsen og Jürgensen med henholdsvis 14 og 8 mand $i$ deres brød. I 1856/57 havde Aabenraa den største koncentration: Terkel Andersens værft havde da 70, J. Paulsens 80, Mads Michelsens 38-44 og Peter Lunds 16 arbejdere, tilsammen ca. 207 (1861 var det stort set uændret med 206). Bruhns værft på Kalvø havde i 1856/ 5732 mand (1861: 21). På vestkysten fandtes Lorenzen \& Petersens bådebyggeri i Wyk med 10 mand (1861: 12).

Desværre rummer listerne fra 1856/57 ikke oplysninger fra Flensborg; de findes først i 1863, hvor der var tre værfter i denne by: Weedermanns med 20, Johan Hansen jr.s med 23 og J.P. Christiansens med 30 mand. Derudover nævner listen fra 1863 kun Bruhns værft på Kalvø med 36 mand, bådebyggeriet i Wyk med 10 og Hollers ved Vorwerk med 40. Tal fra Sønderborg savnes helt. Lægges tallene fra $1856 / 57$ sammen med oplysningerne om Flensborg fra 1863, fås en samlet beskæftigelse i den slesvigske skibsbygningsindustri omkring 1860 på tæut ved 500 mand. Det rakte til en fjerdeplads efter teglværkerne, jernstøberierne og tobaksfabrikkerne. 


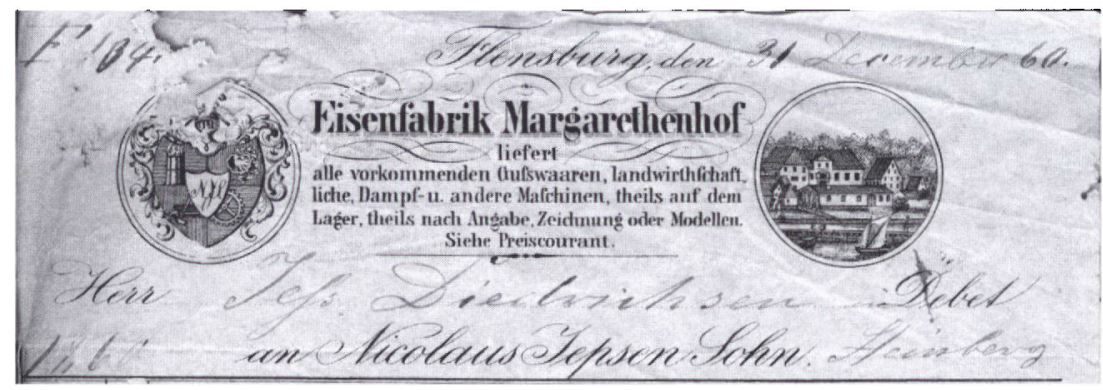

Jernstoberiernes centrale rolle $i$ den tidlige industrialisering skyldtes ikke mindst, at de leverede maskiner til de andre brancher. På dette regningshoved fra Nicolaus Jepsen Sohns stoberi og maskinfabrik Margarethenhof i Flensborg fra 1860 næones bl.a. dampmaskiner. Arkivet ved Dansk Centralbibliotek for Sydslesvig P 192-3.

\section{Konklusion}

Den tidlige industrialisering i hertugdømmet Slesvig foregik i nøje overensstemmelse med de internationale konjunkturer med væksten koncentreret $\mathrm{i}$ årene 1830-1857. Dels skete der en kvalitativ udvikling i retning af en mere moderne industri, som så småt var begyndt i 1820 'erne og som afviklede protoindustrielle manufakturer og forlagsindustrier som kniplingsproduktionen til fordel navnlig for bl.a. en række nyanlagte jernstøberier. Dels var der en betydelig kvantitativ vækst $i$ antallet af industrivirksomheder med mindst seks ansatte fra ca. 80 i 1830 til ca. 260 i 1857 og i samme periode en forøgelse i antallet af industriarbejdere fra ca. 1500 til ca. 5200. Udover den nye jernindustri kom væksten ikke mindst den traditionelle teglproduktion, som blev landsdelens største enkelte industribranche, til gode. Næst efter teglværkerne og jernstøberierne beskæftigede tobaksfabrikkerne mange, og her var der ligeledes en betydelig vækst. På fjerdepladsen kom efter alt at dømme skibsværfterne. Væksten blev afbrudt af den internationale krise i 1857, som bevirkede et mærkbart, men ikke katastrofalt tilbageslag. Dette kom efter alt at dømme først efter hertugdømmets indlemmelse i Tyskland i 1864, der krævede en hård omstilling, som langtfra alle industrier kunne klare.

\section{Fabrikslister}

1811: RA, Generaltoldkammer- og Kommercekollegiet. Industri- og fabriksfagenes sekretariat, nr. 1565, Fabriksliste for hertugdømmerne 1811; nr. 1562, do. 1808-09 
(Aabenraa og Logumkloster 1809); nr. 1564, do. 1810 (Slogs herred); nr. 1566, do. 1812-16 (Flensborg amt 1812).

1830: RA, Generaltoldkammer- og Kommercekollegiet 1816-48. Industri- og fabrikskontoret nr. 2625, Industritabel for Slesvig 1830; nr. 2626, do. 1831 (Flensborg amt) og nr. 2627, do. 1832 (Haderslev amt, men tal for 1831). Carlshütte mangler, da virksomheden indsendte særskilt beretning, som ikke er fundet, i stedet arbejdertal for 1830 fra Haase s. 241.

1837: RA, Generaltoldkammer- og Kommercekollegiet 1816-48. Industri- og fabrikskontoret nr. 2632, Industritabel for Slesvig 1837. Arbejdertal for Carlshütte 1837 fra Haase s. 241.

1845: RA, Generaltoldkammer- og Kommercekollegiet 1816-48. Industri- og fabrikskontoret, nr. 2636, Industritabeller for Slesvig 1844-45 (S 16/2220-2221). Arbejdertal for Carlshütte 1845 fra Haase s. 241.

1851: RA, Ministeriet for Hertugdømmet Slesvig, 1. Dept. B nr. 130, Lister over fabrikker og næringsdrivende i hertugdømmet Slesvig 1848-1851 (Aabenraa amt 1851, Flensborg, Husum og Bredsted amter 1850, Ejdersted landskab og Hütten amt 1851, Gottorp amt og 1. Angler godsdistrikter 1850, Gråstenske godser 1851, Tender og Aabenraa 1851, Friedrichstadt og Slesvig 1850). Sst. 2. Dept. B nr. 389 , Industri- og fabrikssager 1852-53 (Egernførde $1850 \mathrm{og}$ Augustenborgske distrikt 1851), LAA, Haderslev amtsarkiv, journalsag 280/1853 (Haderslev by og amt 1851). LA $\AA$, Aabenraa amtsarkiv, journalsag 1853 IX nr. 2 (Sønderborg amt 1851). LAA, Tønder amtsarkiv T 39, Industri, alm. sager (Tønder amt 1852). LA $\AA$, Sønderborg byarkiv nr. 128 (Sønderborg 1847). Stadtarchiv Flensburg A 423 (Flensborg 1853). Arbejdertal for Carlshütte 1851 fra Lemburg s. 44. Tal mangler fra Husum og Tonning.

1857: RA, Ministeriet for Hertugdømmet Slesvig, 2. Dept. B nr. 401A, Fabrikker etc. 1856-1858. Arbejdertal for Walthers papirfabrik i Flensborg og kniplingefabrikant Hanquist i Tønder fra listen for 1856. Arbejdertal for Christiansdal (spejlsliberi m.m.) fra listen for 1860 (Sst. nr. 400, se 1861).

1861: RA, Ministeriet for Hertugdømmet Slesvig, 1. Dept. B nr. 105, Fabrikker m.m. 1861-62. Sst. nr. 400, Forskellige sager, fortegnelser over industri og fabriksanlæg i landdistrikterne og byerne 1860-62. Tal for Tønder by fra J. P. Trap: Statistisktopographisk Beskrivelse af Hertugdømmet Slesvig, Kbh. 1864, Speciel Del s. 137. Tal mangler fra Flensborg.

1863: LASH Abt. 62.1., Schleswigsche Regierung zu Schleswig, Nr. 232 I-II: Die bis zum 6. Febr. (1865) bei der Regierung eingegangenen Verzeichnisse der Fabriken und Industrieanlagen im Hzgt. Schleswig 1865; Abt. 61, Schleswig-Holsteinische Landesregierung in Schleswig, Nr. 99: Betr. Fabriken und Industrieanlagen 1865. Jernstøberiet i Tønder: Tal for 1861, se ovenfor.

\section{LITTERATUR}

Albrecht, Ulrike: Das Gewerbe Flensburgs von 1770 bis 1870 . Eine wirtschaftsgeschichtliche Untersuchung auf der Grundlage von Fabriksberichten. SWSGSH Band 24, Neumünster 1993.

Andersen, Poul: Graasten - et slot og et sogn, Graasten 1986.

Brockstedt, Jürgen (red.): Frühindustri- alisierung in Schleswig-Holstein, anderen norddeutschen Ländern und Dänemark. SWSGSH Band 5, Neumünster 1983.

Brockstedt, Jürgen (red.): Wirtschaftliche Wechsellagen in Schleswig-Holstein vom Mittelalter bis zur Gegenwart. SWSGSH Band 20, Neumünster 1991. 
Fangel, Henrik: Haderslev bys historie I, Haderslev 1975; II, Haderslev og Aabenraa 1996.

Flensburg. Geschichte einer Grenzstadt, Flensburg 1966.

Haase, Nicolai: Das Aufkommen des gewerblichen Grossbetriebes in Schleswig-Holstein (bis zum Jahre 1845). Kiel 1925.

Hansen, Sv.Aa.: Økonomisk vækst i Danmark, I, Kbh. 1976.

Harsberg, Vibeke: Træk af den sønderjyske industris udvikling 1850-1864. Aabenraa 1988.

Henningsen, Lars N.: Fattigvæsnet i de sønderjyske købstæder 1736-1841, Aabenraa 1978.

Henningsen, Lars N.: Jernstøberier og maskinfabrikker i Nordslesvig indtil ca. 1900 (Sønderjyske Årbøger 1982, s. 137-162).

Henningsen, Lars N.: Sønderjyllands tidligste industrialisering for 1864 personer og konjunkturer (Industrihistorisk Selskab for Senderjyllands skrift nr. 1, 1992).

Johansen, H.C.: Industri (Den Store Danske Encyklopædi bd. 9, Kbh. 1997, s. 359-361).

Lemburg, Jens-Uwe: Arbeit auf der Hütte. Zur wirtschaftlichen und sozialen Entwicklung Rendsburgs 18501914 unter besonderer Berücksichtigung der Arbeiterschaft der Carlshütte. SWSGSH Band 18, Neumünster 1990.

Momsen, Ingwer E. (red.): SchleswigHolsteins Weg in die Moderne. SWSGSH Band 15, Neumünster 1988.

Nielsen, Leif Hansen: Ad industriens vej. Studier i den slesvig-holstenske industri 1864-1914 med særlig henblik på udviklingen i Nordslesvig. Ph.d. afhandling. Syddansk Universitet 2005.

Rawert, O.J.: Kongeriget Danmarks industrielle Forhold fra de æeldste Tider indtil Begyndelsen af 1848 . Kobenhavn 1850 /Skippershoved $\mathrm{u}$. år.

Rheinheimer, Martin: Bibliographie zur Wirtschafts- und Sozialgeschichte Schleswig-Holsteins. SWSGSH Band 27, Neumünster 1997.

Svensson, Bjørn: Industrieventyret i Kristiansdal (Sønderjysk Mănedsskrift 1971, s. 332-343).
Vaagt, Gerd: Die frühe Industrialisierung im Herzogtum Schleswig (Flensburg 700 Jahre Stadt, I, Flensburg 1984, s. 297-320).

\section{NOTER OG HENVISNINGER}

1. Om den ældste industri, se Haase.

2. Leif Hansen Nielsen: Ad industriens vej. Studier i den slesvigholstenske industri 1864-1914 med særlig henblik på Nordslesvig. Under udgivelse.

3. En fuldstændig oversigt over den industrihistoriske litteratur findes hos Rheinheimer s. 198-248.

4. Listernes tilblivelse og kildeværdi analyseres indgående hos Albrecht s. 24-53.

5. F.eks. var der en tilbagegang på $16 \%$ i beskæftigelsen i jernstøberier og maskinfabrikker, skønt antallet af virksomheder her var oget. Tilsvarende ses ved papirfabrikkerne og tobaksfabrikkerne. Se tabel 1 og 2.

6. Hvilket formentlig også er grunden til, at Marcussens berømte orgelfabrik i Aabenraa ikke findes på listerne.

7. En "Blumenfabrik" i Slesvig er undtagelsen, som bekræfter denne regel. Den er ikke medtaget i tabellerne.

8. Definition fra Hans Chr. Johansen anf. leksikonartikel.

9. Se herom Lars N. Henningsen: Fattigvæsnet s. 98-111.

10. Leif Hansen Nielsen anf. afh. s. 34 .

11. Herom Jürgen Brockstedt: Konjunkturen in der Wirtschaftsentwicklung Schleswig-Holsteins 1864-1913, mit einem Überblick der Periode 1773-1864 (i samme (red.): Wirtschaftliche Wechsellagen s. 221-263, om tiden indtil 1864, se s. 230-236).

12. Jfr. note 7. Poul Andersen s. 52.

13. Haase s. 203-206.

14. Se generelt Peter Wulffs afhandling i Brockstedt: Frühindustrialisierung.

15. Harsberg s. $19 f$. 
16. Gerd Vaagt: Die frühe Industrialisierung im Herzogtum Schleswig; Lars N. Henningsen: Jernstøberier og maskinfabrikker; Fabriksliste 1857. Do. 1861 (Peter Petersen i Sønderborg, da H. English). Trap I s. 137 (Lorenzen i Tønder).

17. Vaagt anf. afh. og Henningsen: Jernstøberier og maskinfabrikker.

18. Se herom Bjørn Svensson.

19. Tallene fra Flensborg mangler. For Slesvig uden Flensborg var de: 1857216 fabrikker med 4272 arbejdere, 1861190 fabrikker med 3643 arbejdere og 1863176 fabrikker med 3265 arbejdere.

20. Antallet af industriarbejdere i Slesvig 1857 udgiorde $1,31 \%$ af befolkningen i 1855, mens de næppe mere end 20.000 industriarbejdere i Kongeriget (Sv. Aa. Hansen I s. 150 ) udgjorde $1,33 \%$ - heri indbefattet tallene for Kobenhavn.

21. Flensburg. Geschichte einer Grenzstadt s. 356f.

22. Fangel: Haderslev bys historie I s. 549-552 og II s. 80f.

23. Beregning på grundlag af Leif Hansen Nielsen anf. afh., bilagstabel A1.

24. Rawert s. 794. På s. 617 nævnes fire kniplingskræmmere $\mathbf{i}$ enklaverne: Mads Madsen og Dines Hansen i Mogeltønder, Wulff og A. M. Winther $i$ Brede med tilsammen mindst 900 kniplepiger!

25. Harsberg s. 84f, 90-92. 